International Journal of Linguistics, Literature and Culture
Available online at https://sloap.org/journals/index.php/ijllc/
Vol. 6, No. 6, November 2020, pages: 36-47
ISSN: 2455-8028
https://doi.org/10.21744/ijllc.v6n6.1034

\title{
Changes in Work Ethos of Balinese Who Have Worked on Cruise Ship and its Implications for Religious Life and Social Culture
}

\section{Article history:}

Submitted: 27 September 2020

Revised: 09 October 2020

Accepted: 18 November 2020

\section{Keywords:}

cruise ships;

globalization;

religion;

socio-culture;

work culture;

\begin{abstract}
This article intends to examine the changes in the work ethic of Balinese people who have worked on cruise ships and their implications for religious and socio-cultural life. The problems examined in this study are (1) Why is there a change in the work culture of Balinese people who have worked on cruise ships? (2) What is the process of changing the work culture of Balinese who have worked on cruise ships? and (3) What are the implications for religious and socio-cultural life? The purpose of this study is to analyze and find changes in the work ethic (work culture) of Balinese who have worked on cruise ships and their implications for religious and socio-cultural life. The theories used to analyze the above problems are Modernization Theory, Socio-Cultural Change Theory, and Reception Theory. This research uses qualitative methods with religious and cultural approaches. The implementation was carried out in Gianyar Regency and Karangasem Regency which represented the East Bali Province and Tabanan Regency and Buleleng Regency which represented the West Bali Province. The type of data used is qualitative data obtained from primary and secondary data sources.
\end{abstract}

International journal of linguistics, literature and culture (C) 2020. This is an open access article under the CC BY-NC-ND license (https://creativecommons.org/licenses/by-nc-nd/4.0/).

\section{Corresponding author:}

I Nyoman Diana,

Universitas Hindu Indonesia, Denpasar, Indonesia.

Email address: ndiana249@yahoo.com

\footnotetext{
${ }^{a}$ Universitas Hindu Indonesia, Denpasar, Indonesia

${ }^{\mathrm{b}}$ Universitas Hindu Indonesia, Denpasar, Indonesia

${ }^{c}$ Universitas Hindu Indonesia, Denpasar, Indonesia
} 


\section{Introduction}

Balinese society has a perspective that divides social categories into three classifications as one which is also complimentary. This point of view is essentially based on the values that come from Hinduism. The Balinese people acknowledge differences ( rwa bhineda), which are often determined by factors of space (desa), time (kala), and real conditions in the field (patra). The concept of desa, kala, and patra causes Balinese culture to be flexible and selective in accepting and adopting external cultural influences.

The most important ideology upheld by the Balinese people is the Tri Hita Karana ideology which later developed into the teachings of harmony, balance, and at the same time dependence on one another in one living system. It is said so, because, in the view of the Balinese Hindu community, people always try to be balanced towards the natural surroundings. This is based on the awareness that the universe is a complexity of elements that are related to one another and form a universal system. Thus the main value of the Balinese Hindu community is balance or harmony itself (Dharmayudha \& Cantika, 2011).

The Balinese people also believe that prosperity and happiness can be achieved through Catur Purusa Artha, which consists of the four forces or bases of life towards happiness, namely: Dharma, Arta, Kama, and Moksa. These sequences are stages that should not be exchanged because they contain the belief that no meaning can be obtained without going through Dharma; no Kama is obtained without going through Arta, and no Moksa can be attained without going through Dharma, Arta, and Kama.

Dharma, as the main basis, has a comprehensive meaning. Dharma can be defined as obeying all religious teachings as evident from daily thoughts, words, and deeds. Dharma can also be interpreted as fulfilling obligations according to their respective professions or jobs and responsibilities. Furthermore, Arta is something of material value that can be used to meet the physical needs of human life. Arta can be obtained directly or indirectly. Arta that is obtained directly, for example, someone whose obligation is as a farmer who raises cattle, and then he will enjoy the cow's milk. Arta which is obtained indirectly, for example, a father who is diligent in educating his child from childhood properly so that in the future his son becomes a rich and respectable figure so that his child can take care of his father's life in old age properly and adequately. Sufficient Arta can be used to fulfill Kama (Sumada, 2004).

Jobs on cruise ships, in terms of salary, are quite promising. Therefore, hundreds of shipping companies now operate cruise ships. According to data cited by Demartoto (2007), nearly 251 shipping companies operate cruise ships. Four cruise ship companies control $90 \%$ of the world cruise package market, namely Carnival Corporation or Holland America Line (HAL), Royal Caribbean Cruises Limited, Star Cruises, and P\&O Princess. However, the development of COVID-19 made many cruise ship companies affected, so that the job capacity on cruise ships eventually decreased.

In the past, a shipping company could operate/own several cruises, such as (1) Carnival Corporation which controlled $47 \%$ of the world market share in charge of Carnival, P\&O Cruises, Princess Cruises, Holland American Line, Aida Cruises, and Costa Cruises; (2) Royal Caribbean International which controls $22 \%$ of the world market share in charge of Azamara cruises, Celebrity Cruises, and Royal Caribbean; (3) Star Cruises which controls 11\% of the world market share in charge of NCL and Star Cruises; and (4) another group consisting of TUI Cruises, Silversea, Island Cruises, MSC Cruises, Thomson Cruises, Fred Olsen which controls 20\% of the world market share (Sudiarta et al., 2013).

Balinese people working on cruise ships are an attempt to find arta. Arta can be interpreted as something of material value that can be used to meet the physical needs of human life. The purpose of looking for this arta is to obtain kama considering that no kama is obtained without going through the arta. Kama can be defined as desire, affection, love, pleasure, and enjoyment. Desire can provide enjoyment and purpose in life. This enjoyment will give you satisfaction. Kama is a joy and pleasure obtained through the senses. However, it cannot be denied that working on cruise ships carries the risk of cultural influences for Balinese workers who highly uphold Balinese culture based on Hinduism. This condition can occur considering the working environment on cruise ships, especially in the era of globalization which allows for inter-ethnic interactions and multicultural interactions with very high intensity. This is not surprising given that both the workforce and tourists onboard the cruise ships come from a wide variety of ethnic, cultural, religious, and other backgrounds.

The negative influence of working on a cruise ship is because basically, the culture that is on a cruise ship is a culture that upholds hedonic ideology. This hedonist ideology tends to make people behave extravagantly, and spend unlimited amounts of time and often bump into moral and religious boundaries (Parker et al., 2006; Holmes \& Marra, 2002). This is of course contrary to Balinese culture which upholds morals and religion. Besides, culture on

Diana, I. N. ., Gelgel, . I. P. ., \& Dharmika, I. B. . (2020). Changes in work ethos of balinese who have worked on cruise ship and its implications for religious life and social culture. International Journal of Linguistics,

Literature and Culture, 6(6), 36-47. https://doi.org/10.21744/ijllc.v6n6.1034 
cruise ships, especially work culture, also tends to influence Balinese workers who have an argumentative-based communal work culture that shows less disciplined behavior, becomes a very disciplined work culture even followed by the motto of time is money.

Based on this phenomenon, the researcher is interested in researching three main problems, namely (1) why is there a change in the work culture of Balinese who have worked on cruise ships? (2) What is the process of changing the work culture of Balinese who have worked on cruise ships? (2) What are the implications of the change in the work culture of Balinese who have worked on cruise ships for their religious and socio-cultural life?

This research was studied using Modernism Theory, Theory of Socio-Cultural Change, and Reception Theory. Modernization theory includes three things, among others (1) Starting from two dichotomous poles, namely between modern society (societies of developed countries) and traditional societies (communities of developing countries); (2) The role of developed countries is very dominant and is considered positive, namely by transmitting modern values in addition to providing capital and technology assistance. The pressure of development failure is not caused by external but internal factors; (3) The proposed development recipe can apply to anyone, anytime and anywhere.

Meanwhile, the Theory of Socio-Cultural Change was put forward by Karl Marx and Max Weber. Marx (in Giddens, 2013) formulates that social and cultural change is a product of production (materialism), while Max Weber is more about a system of ideas, a system of knowledge, a belief system that is the cause of change. Social change is explained as a transformation in community organizations in thinking patterns and behavior at a certain time. Social change, in this case, occurs at the level of social relations, institutions, and social structures, which are related to micro, mezzo, and macro systems which are also associated with the birth of social actor subjects in encouraging and creating social change.

Apart from the two theories above, the researcher also uses the Reception Theory, which in general confirms that the reader's acceptance, reception, response, reaction, and attitude towards a literary work. There are two types of reception, namely synchronous and diachronic. First, the synchronous reception model can be done through the response of a person or group of people who are deliberately grouped to provide an assessment of literary works. Conclusions are obtained through the diversity of opinions of the groups studied. Meanwhile, the second model, diachronic reception concerning the study of cultural sciences, is more significant because, first, a change has given the work as a result of changes in the horizon of expectations, paradigms, and perspectives. Second, this shift in valuation is a measure of how far society has changed.

\section{Materials and Methods}

This research uses qualitative research methods, namely research that emphasizes efforts to reveal the meaning behind every action (human behavior), both in the form of policies and behaviors displayed by the actors involved in the activity under study. Then data collection was carried out using three techniques, namely observation techniques, in-depth interview techniques, and document study techniques. The data that has been collected is then analyzed using interpretive qualitative analysis.

\section{Results and Discussions}

\subsection{Factors that cause changes in the work culture of Balinese who have worked on cruise ships}

\section{Factors of modernism}

One of the fields of work that has attracted many young Balinese generations is working on cruise ships. The high interest of high school graduates or vocational high school, to work on cruise ships seems to indicate a new trend in job options for Balinese youth. This is evidenced by the growing number of educational institutions promising jobs on cruise ships. Educational institutions like this start programs with basic hospitality and tourism skills. Furthermore, they must intern at hotels or tourism service companies for at least 6 months before they are enrolled in the cruise ship recruitment system. This cannot be separated from the influence of modernism in today's society, including Balinese society, which is marked by the rapid development of industry in Bali, especially the tourism industry. 
Tourism referred to in this context is the cruise ship tourism industry. There is a large growth in the cruise ship industry (Larsen et al., 2012), resulting in many job vacancies available for young people from Southeast Asia, especially from the Philippines and Indonesia. For some reason, transnational yacht companies choose to hire people from both countries. They do recruitment by race (Wood, 2002). The development of the cruise ship industry is now due to the growing popularity of cruise ship tourism among tourists from developed countries, especially those who are retired or recently married.

Prospective cruise ship workers who are currently in training, seem to be going through a difficult period towards a bright future. From the interview with one of the informants, it can be understood that they want to work until they have enough capital to create small businesses such as shops, restaurants, mini-marts, boutiques, workshops, or construction companies. Based on these data it can be understood that the existence of such desires proves that there has been a change in work ethic among Balinese who have worked on cruise ships.

\section{The Influence of globalization on Balinese people working on cruise ships}

Globalization brings a new situation, namely the polarization and stratification of the world population in the globality of the rich and the locality of the poor (Wood, 2000; Kim, 2008; Merta, 2019). This polarization has been accompanied by a situation in the world of life that is fragmented. The cause is not only the result of a shift in the production sector towards the consumption sector but even more devastating is the consequence of modernity reasoning (Featherstone \& Lash, 1999).

In this era of globalization, there are many risks faced by people, including the Balinese. In Balinese society, for example, in the manpower sector, many jobs are opened by the government and the private sector but competition is a major obstacle in finding jobs (Demartoto, 2007). There are different ways that people do to be able to meet their survival. In this case, there is a way for people to change their lifestyle through the work they have. This means that there is a shift in orientation in the field of work. This can be seen in the phenomenon of the number of young people working on cruise ships whose capacity is no longer national but international. Working on a cruise ship is an alternative for young Balinese to earn a higher income. The condition in Indonesia today is that a lot of single men, in particular, dare to go on a voyage even with mediocre skills. The difficulty of finding work domestically is one reason why many young people enjoy working on cruise ships. Working on a cruise ship has many advantages, apart from the material advantage of earning money in dollars, also being able to enjoy visiting places around the world where the ship will stop and anchor. The crews of this cruise ship hold employment contracts for 12 months. Consisting of 10 months of work and 2 months of leave. They usually work 10 to 13 hours per day for 7 days a week. Cruise waiters may work up to 16 hours per day. Sleep at most 6 hours every night. Ironically, work contracts often require workers to work 80 hours a week.

Maybe many people think that the world of cruise ships promises a life of glamor and luxury. People who work overseas/cruise ships usually get the label, namely the new rich. The circulating stereotype that workers abroad must have a lot of money indirectly also causes working abroad/cruise ships to become a tremendous magnet for some job seekers in Indonesia. When compared to the salaries of private employees in Indonesia, salaries abroad can indeed be many times higher, but if other factors are considered, such as social and mental factors, the multiplied value can be universally equal when compared to salaries in Indonesia.

The majority of cruise ship crews from Bali have no other choice and they are employed in a heavy working atmosphere, they choose to stay to support their families in the country. From an economic perspective, the life of cruise ship workers is better than the average for other residents. The salary for cruise crews ranges from the US $\$$ 1,500-2,000 per month so that on average they have an income of 20 million per month.

Various social processes and social relations involving technology, nature, and social actors (production, consumption, transportation, medicine, work) not only produce and consume "social products", but also "produce" and "consume" various "Risk", whether physical, psychological, or social. Social machines that are aimed at producing social products (health, security, wealth, prosperity) are now at the same time become "social risk machines".

This new modernization will in turn produce risks as well as produce reflexivity that allows it to question itself about the risks it creates. Furthermore, those who are victims of a risk begin to think about it and at the same time think of efforts to minimize it. Young people now have a broad view that is no longer on a national scale but a global scale, and this is the effect of modernity. With modernization, they assume that work as their parents used to be less challenging and less progressive. They think that their parents' work is monotonous and without any hope for more development. Modernity has dissolved the structure of feudal society and produced an industrial society (Dahana,

Diana, I. N. ., Gelgel, . I. P. ., \& Dharmika, I. B. . (2020). Changes in work ethos of balinese who have worked on cruise ship and its implications for religious life and social culture. International Journal of Linguistics, Literature and Culture, 6(6), 36-47. https://doi.org/10.21744/ijllc.v6n6.1034 
2004). Thus there has been a change in the work ethic of Balinese people who have worked on cruise ships because they often come into contact with the values of globalization.

The work ethic of western people is orientated by the society of the eastern world

The workforce in Bali Province increases annually by 15,000 people. This shows that employment in Bali Province is growing, especially in the tourism service sector and the informal sector. The tourism service sector started to revive after the Bali bombing II in 2005, which was accompanied by the development of the informal sector to serve workers in the tourism sector. Types of professions in the tourism context that have been certified are a tour guide, front offices, food preparation, housekeeping (room or attendant), product (kitchen), and SPA therapy. However, along with the emergence of an awareness of the importance of professional certification for workers in tourism, sooner or later the interest in tourism workers to take professional competency certification exams will increase along with the requirements demanded by professional organizations to become members.

Entering the free trade negotiation forum, Bali, which is part of Indonesia that has committed and participated in at least seven types of trade agreements, will of course receive the positive and negative impacts of this free trade. The negative impact, especially related to manpower, is the increasing number of foreign workers entering Bali who work in various sectors. However, most of them work in activities related to tourism services, such as trade and restaurants, hotels, and in the transport, warehousing and communications sector, and other service sectors. Some of them work for foreign companies and some also work for domestic companies whose professionalism is needed by the company.

This fact shows that Bali is also an attractive location to work for foreign workers. Besides, many foreigners earn a fortune in Bali illegally, who are engaged in various fields of creativity and foreign trade by taking advantage of the fame of the Balinese name abroad. Thus, free trade in products and services has two sides, namely a positive side in the form of blessings for consumers and a certain group of people, and a negative side in the form of a disaster for local product producers or a certain group of people. However, due to the strong orientation of the Balinese people towards the work ethic of Westerners, the negative impacts of Western culture are often overlooked.

Free trade is an economic concept that refers to the Harmonized Commodity Description and Coding System with the provisions of the World Customs Organization based in Brussels, Belgium, that the sale of products between countries without export-import taxes or other trade barriers. Free trade can also be defined as the absence of artificial barriers (barriers imposed by the government) in trade between individuals and between companies located in different countries.

Friedman (1999) describes that the population of the whole world will prosper if all countries in the world are willing to open their borders to do market liberalization. Goods can go in and out freely, and so an investment. International trade and investment will also bring world peace. Countries choose not to go to war because their economies are linked to one another. Very provocatively, Friedman said that free trade plus free market produces prosperity plus peace.

\subsection{The Process of changing the work culture of Balinese people who have worked on cruise ships}

\section{The process of changing work culture in the middle of the globalization vortex}

It is undeniable that working on a cruise ship means working in the vortex of globalization. This means that the process of changing the work culture of Balinese who have worked on cruise ships can also be interpreted as a process of changing work culture in the globalization vortex. Globalization has shaped the civilization of the era by incorporating a practical and pragmatic lifestyle. Even globalization has become a new ism or stream among Balinese people by diverting practical ideas of life such as materialism, hedonism, and consumptive nature. This is what then puts the Balinese in a position that is sometimes cornered, which is identical to a group whose lives are wrapped in the comfort of the civilization of capitalism. At a more micro level, this discussion aims to see what is happening among Balinese people, especially Balinese people who have worked on cruise ships in response to the increasingly uncertain direction of globalization.

Through the logic of globalization, the aspects of the local culture at that time were merged into a series of subordinations of national culture which Atmadja (2010), considered to obscure the meaning of noble regional culture. Atmadja (2010), suspected that the most extreme condition was when young people who received adequate 
education in customary villages chose to pursue non-agricultural fields, such as labor, traders, private employees, and other professions.

When Balinese who have worked on cruise ships are successful and proclaim themselves as the new rich class of people, they tend to strengthen their social class position through the educational opportunities they have obtained. The conditions that were also formed by the transportation and communication revolution are then suspected of giving more heterogeneous features to the grouping of community members which previously only relied on the separation of caste, strata, and other social classes (Atmadja, 2010).

This is in line with the struggle for the original identity of the Balinese people both in the socio-cultural sphere Vis globalization which has begun to surface. Various problems that surround the community are faced with the reality of the current social change whose influence is getting stronger until a kind of alert culture movement emerges, namely the safeguard for the preservation of Balinese tradition which later became popular as Ajeg Bali. It is a great discourse on the preservation of Balinese culture that every generation, including young people, must have in response to the direction of global change that is rapidly moving, including free trade, eco-tourism, and various other global demands.

Furthermore, this discourse implies that the threats to be aware of do not actually come from within, but always come from outside Bali. In this context, there is an affirmation of the strict cultural boundaries between Bali and from outside Bali. The culture from Bali is transmitted as Balinese people who maintain order while maintaining traditions. While culture from outside Bali is defined as foreign culture, the impact of globalization includes the influence of migrants.

The process of changing the work culture of Balinese people who have worked on cruise ships as with other tourism influences on young people has created a situation of anxiety so that the Balinese people need to carry out a re-enforcement of Balinese culture as a solution to overcoming various problems. In the context of young people's attitudes towards cultural invasion, for example, they are more progressive, innovative, and at the same time sensitive to change. For example the attitude towards the indication of the capitalization of Balinese cultural arts.

As illustrated by Suyadnya (2010), youth groups in Bali tend to think that without sufficient skills, they will be optimistic about getting a place to work in the tourism services sector, especially hospitality tourism services including working on cruise ships. However, it is unfortunate that the cruise ships employ Balinese only in the sector of work that is not directly related to the policymaking process or in other words Balinese who work on cruise ships are limited as laborers or workers, not up to the level of management so that sometimes they are detrimental to their position.

\subsection{Process of Changing Work Culture through Social Change}

The Balinese are generally engaged in agrarian work, as shown by their need for the Balinese calendar to deal with the climate. Therefore they have the mentality of a peasant culture with characteristics, among others, being homogeneous given oriented to the past with a slight variation in orientation to the present a sense of kinship and social solidarity are the main values his view that humans submit to nature and try to live in harmony with nature; and they are in substantive economic conditions. Also, they live in a social unit called Banjar and the village of pakraman.

However changes whether consciously or not, are experienced by every individual and society, including Balinese, especially Balinese who have worked on cruise ships. The certainty of this change, as emphasized by Triguna (2002), is that universally there is not a single society and culture in the world that lives statically without undergoing a process of change. Change can take place naturally or planned, therefore Atmadja (2005), states that every society cannot escape from socio-cultural changes, whether caused by innovation and cultural diffusion, or development. The fact that these three factors led to many changes in a short time caused the community to experience socio-cultural tensions.

Likewise, the change in work culture brought by Balinese who work on cruise ships as a model of the modernization process does not all have positive implications for a social life because the development process cannot be completely controlled and directed. The development paradigm in developing countries rests more on the Rostow theory of economic growth, which is oriented towards industrial development (Lubis, 2004; Fakih, 2005; Suhanadji \& Waspodo, 2006). As a result, development, which is a planned change that puts more emphasis on welfare, is not entirely controllable and directed based on community needs. The goal of welfare is the realization of a modern society marked by the adoption of Western culture.

Diana, I. N. ., Gelgel, . I. P. ., \& Dharmika, I. B. . (2020). Changes in work ethos of balinese who have worked on cruise ship and its implications for religious life and social culture. International Journal of Linguistics, Literature and Culture, 6(6), 36-47. https://doi.org/10.21744/ijllc.v6n6.1034 
The work culture brought by Balinese who have worked on cruise ships is one of the correlational variables (Suhanadji \& Waspodo, 2006). The rapid process of modernization and industrialization, including the tourism industry, has opened wider and more diverse socio-cultural interactions, such as business interactions, political interactions, and cultural interactions. Business interactions are interactions that place economic activities as their material basis. Political interactions are interactions where cultural relations can create dependence from one culture to another. Then, cultural interaction is a form of relationship that places the socio-cultural basis into which it is capitalized (Sunaryo, 2000). This cultural interaction is formed because of a meeting between two or more citizens of supporters of different cultures. The intensity of this meeting resulted in the emergence of mutual influence and mutually reinforcing one of the elements of culture to form a new culture. This is possible because Bali tourism absorbs a lot of workforces, not all of which can be provided only based on traditional Balinese knowledge and skills (Sukarma, 2008). As a result, efforts to preserve local culture must deal with a development that tends to lead to modernization and industrialization, which is nothing but a westernization process.

The social changes of Balinese people caused by tourism activities, including changes in the work culture brought by Balinese who have worked on cruise ships in the perspective of social change, refers to the social system, which at least contains six components, namely changes in composition, changes in structure, changes in function, changes in boundaries, changes in the relationship between subsystems, and changes in the environment. This is why social change can occur at various levels of life, such as individuals, interactions, organizations, social institutions, communities, and globally (Lauer, 2003). In addition to the cultural dimension, changes in the Balinese people about tourism can also be observed through the social dimension, especially with this social system theory. Given that social and cultural phenomena are two symptoms of one reality, namely a system of human action based on a knowledge system in which there is an inseparable relationship between humans and nature and their culture (Berger, 1994). In this case, it can be assumed that every social and cultural action takes place in a spatial setting, therefore the components of environmental change are discussed separately as physical changes.

The change in the work culture of Balinese who have worked on cruise ships in the context of cultural heritage, Ardika (2006), explains that culture is like a double-edged knife, especially in the use of cultural heritage as an object and tourist attraction. Citing Burns and Holden's opinion, Ardika (2006), said that on the one hand tourism can preserve cultural heritage, while on the other hand tourism activities can damage or harm this cultural heritage. However, until now there have not been found effective ways to overcome the negative impacts of tourism, including the narrowing of agricultural land as a result of a large number of agricultural land conversion for tourism purposes. This is as shown by Sukawati (2004), that in the Ubud area there has been so much conversion of agricultural land into a tourism area.

\subsection{Implications of Changes in the Work Culture of Balinese People Who Have Worked on Cruise Ships on their Religious and Social Cultural Life}

\section{Implications for Religious Life}

The discussion on the implications of the change in the work culture of Balinese who have worked on cruise ships for religious life, begins with a discussion of ideology, considering that ideology precedes religion (Barrett, 2000; Tan, 2006). Ideology refers to the characteristics of beliefs, values, and norms that are prominent in society or some parts of society. Trust provides cognitive assumptions about what is right and what is wrong. This belief concerns the nature of the universe, what child education techniques can produce children with healthy personalities, what differences exist between men and women, and others. Value is the concept of something of value that is defined socially. It determines our understanding of what is good and bad, beautiful or bad, liked or disliked, and so on. Meanwhile, norms show common standards or rules relating to appropriate and inappropriate social actions. They are orders and prohibitions that society tries to instill in its members. All societies create beliefs, values, and norms, but the diversity of these phenomena is enormous.

The young generation of Bali no longer wants to be farmers, especially for those whose parents have sold their fields, so they no longer own land. Initially, they chose to work on cruise ships to raise capital. After that, they prefer to make a living by opening a business that they think is more profitable. This way they can adapt to the work culture they get on cruises. Based on the explanation above, it is known that it seems that humans have an essence as an ideological creature that cannot be separated from it, as if ideology is the air where humans breathe in to live. With the existence of an ideology, it can help humans to get the resources to fulfill the needs of themselves and their groups, as well as prevent their opponents from getting the same thing. 
The condition of Balinese society with an agrarian culture is in line with the expression given by Scott (1981), that after all, Balinese people who have an agrarian culture are like people who have drowned enough. Scott dialectically describes that moral perception is the basis of every action of the Balinese, which has an agrarian culture in its activities. Morally, Balinese with an agrarian culture will not take dangerous, high-risk actions and threaten their level of subsistence, but dialectically Popkin (1986), shows that it is not a matter of morality that determines every action of an agrarian Balinese society but rationality it works. In Popkins' view, Balinese people with an agrarian culture do not want to take risks in all their actions. Balinese people's perceptions are often influenced by speculative aspects and clever calculations of profit and loss (Hidayaturrahman, 2014).

Furthermore, regarding religion, religion contains shared beliefs and values that intersect with the belief in the power and power of something 'supernatural. The existence, power, and power are generally considered to directly interfere with the running of a society or at least have an indirect relationship with it. Like many components of the sociocultural system, religion is a universal feature of Russian social life.

There has been no change in religious aspects of Balinese social life after working on cruise ships because religion is a belief that is the right of everyone. However, religion too, especially Hinduism, which is the religion of the majority of Balinese people, provides religious values that can be practiced to be grateful for the blessings and fortunes that are obtained. This is indicated by the fact that there are still frequent practices of performing religious ceremonies that aim to strengthen the brotherhood.

Balinese Hindus uphold the teachings of Tri Hita Karana. The worship of the gods, which is an effort to empower spiritual resources, in this case, Lord Brahma, as Brahman resources so that his business is maintained. After the Tri Hita Karana teachings, the next teaching is about tri kaya parisudha, namely kayika (doing good), wacika (saying good words), and manacika (having holy thoughts and knowledge). The working of the basic human capital is believed to be the main capital in developing quality Hindu human resources.

Finally, some of the local Balinese Hindu values that are also considered to be the basis for modern Balinese behavior today include puputan value (sincere, selfless sacrifice), nyalanang jengah (turning ideas into reality), metaksu (charismatic in the profession), mulatsarira (self-introspection), and social values such as paras paros sarpanaya (learning along and in line for the common interest), segilik seguluk sebayantaka (good and bad felt together), and saling asah (learning), saling asih (love each other), lan saling asuh (always give each other control).

\subsection{Implications for Social and Cultural Life}

The implications of the change in the work culture of Balinese who have worked on cruise ships for their socioculture also have an impact on changes in the social structure of their society. The social structure that has changed includes changes in social stratification, the emergence of ethnic groups other than Balinese, changes in policies related to land use, the sexual division of labor, kinship and kinship systems, and education (Sanderson, 2011). According to Sanderson (2011), the components of the sociocultural system contain regular patterns of social life that are used among members of society, in addition to the social patterns that are included in infrastructure. It should be noted that social structure always refers to actual patterns of behavior, as opposed to the impressions or mental conceptions that people have of those patterns. In other words, the social structure contains what people do, not what they say they do, nor what they think they do or think they should do. For this purpose, the social structure contains six sub-units namely (1) presence (or absence) of social stratification; (2) presence (or absence) of ethnic and racial stratification; (3) politics; (4) sexual division of labor and sexual incarnation; (5) family and kinship; and (6) education (Sanderson, 2011).

Related to social stratification, it refers to the existence of groups in society who are not equal in wealth and power. Not all societies have social stratification. In studying a society, it is very important to know whether there is stratification in it or not, if any the nature and level of the stratification must also be known with certainty (Sanderson, 2011). Changes in social structures that are directly related to changes in the work culture of Balinese who have worked on cruise ships are the social stratifications formed in Balinese society. Because of the view that Bali is a tourism area, people tend to choose to work in the tourism sector. In the tourism sector, it is divided into 2 strata, namely the tourism business owner group and the tourism labor group. Balinese who have worked on cruise ships generally belong to the tourism owner group. They are generally from the wealthy clan and cooperate with workers/employees to run their business. This phenomenon has led to a new social structure, namely entrepreneurs in the tourism sector, ex cruise ship workers. This is in line with Sanderson's (2011), explanation, that social stratification refers to the existence of groups that are not equal in wealth and power. Tourism business owners are not as powerful and wealthy as tourism workers.

Diana, I. N. ., Gelgel, . I. P. ., \& Dharmika, I. B. . (2020). Changes in work ethos of balinese who have worked on cruise ship and its implications for religious life and social culture. International Journal of Linguistics, Literature and Culture, 6(6), 36-47. https://doi.org/10.21744/ijllc.v6n6.1034 
Tourism business owners who have worked on cruise ships have hegemony and even dominate labor in the tourism sector. This is following Gramsci's view which states that counter-hegemony is a party that continually organizes and reorganizes life, both consciously and unconsciously from the masses. Efforts to save tourism workers are carried out by maintaining their remaining existence and the number is very small, with counter-hegemony (Tilaar, 2003). This kind of thing can be described as the strategy of the capital owners in fighting the hegemony of the ruler, namely the local government, by trying to defend their business. This is in line with the views expressed by Gramsci in the discussion of his theory, namely providing solutions to fight hegemony (counter-hegemony) by focusing on efforts to improve the standard of living of the community.

The whole phenomenon above is evidence that the work culture brought by Balinese who have worked on cruise ships has changed the social structure, especially the emergence of social stratification of tourism capital owners and labor. The owners of capital become a group that is above tourism workers. This can be seen from the discourse on the terms "boss" for the owner of capital and "subordinate" for the workers. I studied semiotics, the value of the feeling of boss and subordinates shows different social classes.

In Balinese society, before being influenced by the culture of those who have worked on cruise ships, this sexual division of labor is very clear. Women are more occupied to carry out domestic roles, while men play a more external role as breadwinners of the family. However, after the rapid development of tourism in Bali where many tourism-related business centers have sprung up Bali, these new business centers require a workforce of not only male workers but also female workers. From here, women in Bali are also interested in playing a role in earning a living for their families, either as additional income or as the main income to replace their husbands who cannot earn a living.

\section{Conclusion}

Factors causing changes in the work culture of Balinese who have worked on cruise ships are modernization factors that respect the work of employees or other people even though they have a small contribution. Working on a cruise ship means finding a separate way for workers to survive by changing their lifestyle and work, namely by shifting orientation in the field of work. Working on a cruise ship has many advantages, but there are also downsides. However, every job has its risks; working on a cruise ship does not always beneficial because many risks occur to the worker concerned. The risks of young people working in navigation are social. For example, when their original culture emphasized sincerity (not expecting anything in return) in building relationships with other people, it changed to an emphasis on certain interests in building relationships with others.

The process of changing the work culture of the Balinese who have worked on cruise ships through social changes amid the globalization that they have experienced while working on cruise ships where everything is judged by international standards. Balinese people with their traditional values cannot avoid themselves and have to deal with new values in the global economic order, especially when working on cruise ships. Contrasting traditional values with the values of modernism and globalization in the context of life on cruise ships is a counterproductive discourse. The two must be seen as complementary and complementary forces. Modernism and globalization in the context of cruise ships must first be faced with a critical attitude and at the same time reinterpret traditional values that are less relevant and functional. This means that the stimulation of traditional and traditional life is a must; meanwhile, the adaptation of modernity is not something that should be taboo. Therefore, to be able to produce the most suitable model for the situation of Balinese who have worked on cruise ships, it is necessary to study models of adaptation and adoption of elements of modern culture on an ongoing basis.

The implications of the change in the work culture of Balinese who have worked on cruise ships for their religious and socio-cultural life include implications for technology, economy, and ecology. This can be seen from changes in social stratification, the emergence of other ethnicities besides Bali, changes in policies related to land use, the sexual division of labor, kinship, and kinship systems. Furthermore, changes in the social structure of course also have implications at the superstructure level which includes ideology, religion, science, and culture. 
Conflict of interest statement

The authors declared that they have no competing interests.

Statement of authorship

The authors have a responsibility for the conception and design of the study. The authors have approved the final article.

Acknowledgments

We are grateful to two anonymous reviewers for their valuable comments on the earlier version of this paper.

Diana, I. N. ., Gelgel, . I. P. ., \& Dharmika, I. B. . (2020). Changes in work ethos of balinese who have worked on cruise ship and its implications for religious life and social culture. International Journal of Linguistics, Literature and Culture, 6(6), 36-47. https://doi.org/10.21744/ijllc.v6n6.1034 


\section{References}

Ardika, I.W. (2006). Management of Cultural Heritage as Tourism Objects and Attractions in Bali (in Bali Rises, Bali Returns). Denpasar: Collaboration between the Ministry of Culture and Tourism of the Republic of Indonesia and Udayana University.

Atmadja, N. B. (2010). Ajeg Bali; Gerakan, Identitas Kultural, dan Globalisasi: Gerakan, Identitas Kultural, dan Modernisasi. LKIS Pelangi Aksara.

Atmadja, N.B. (2005). Bali in the era of globalization: the island of a thousand temples is not as beautiful as it looks. Yogyakarta: LKiS.

Barrett, J. L. (2000). Exploring the natural foundations of religion. Trends in cognitive sciences, 4(1), 29-34. https://doi.org/10.1016/S1364-6613(99)01419-9

Berger, P.L. (1994). Holy Heaven: Religion as Social Reality. (translation: The Scred Canopy), Jakarta: LP3ES Library.

Dahana, R.P. (2004). Traces of Postmodernism in the Struggle of Indonesian Intellectuals. Yogyakarta: Landscape Publishers.

Demartoto, A. (2007). Mosaics in Sociology. Surakarta: UNS Press.

Dharmayudha, I. M. S. \& Cantika, I W. K. (2011). Balinese Indigenous Philosophy. Denpasar: Literary Upada.

Fakih, M. (2005). The collapse of the theory of development and globalization. Yogyakarta: Student Library.

Featherstone, M., \& Lash, S. (Eds.). (1999). Spaces of culture: City, nation, world. Sage.

Friedman, T. (1999). The Lexus and the Olive Tree. New York: Harper Collins Publishers Inc.

Giddens, A. (2013). The consequences of modernity. John Wiley \& Sons.

Hidayaturrahman. (2014). Local Farmers and Capitalism (Study of Local Farmers' Response to Agricultural Policy in Nungga Village and Maria Village, Bima Regency). Journal of State Administration, Vol. 1.

Holmes, J., \& Marra, M. (2002). Having a laugh at work: How humour contributes to workplace culture. Journal of pragmatics, 34(12), 1683-1710. https://doi.org/10.1016/S0378-2166(02)00032-2

Kim, Y. Y. (2008). Intercultural personhood: Globalization and a way of being. International journal of intercultural relations, 32(4), 359-368. https://doi.org/10.1016/j.ijintrel.2008.04.005

Larsen, S., Marnburg, E., \& Øgaard, T. (2012). Working onboard-Job perception, organizational commitment and job satisfaction in the cruise sector. Tourism Management, 33(3), 592-597. https://doi.org/10.1016/j.tourman.2011.06.014

Lauer, R.H. (2003). Perspectives on Social Change. Jakarta: Rineka Cipta.

Lubis, A. Y. (2004). Is There Still a Footing Place for Scientists. Bogor: Academia.

Merta, I. N. (2019). Social and cultural shifts on art worker community towards current globalization. International research journal of management, IT and social sciences, 6(6), 29-36.

Parker, D., Lawrie, M., \& Hudson, P. (2006). A framework for understanding the development of organisational safety culture. Safety science, 44(6), 551-562. https://doi.org/10.1016/j.ssci.2005.10.004

Popkin, S. (1986). Rational Farmers. Jakarta: Padamu Negeri Foundation Publishing Institute.

Sanderson, S.K. (2011). Macrososiology: An Approach to Social Reality. (Trans. Farid Wajidi and S. Menno). Jakarta: PT. RajaGrafindo Persada.

Scott, J. C. (1981). Moral Economy of Farmers: Upheaval and Subsistence in Southeast Asia. Jakarta: LP3ES.

Sudiarta, I.N., Suardana, I.W., \& Sudana, I. P. (2013). Cruise Ship Tourism: New Market Segments and Bali Readiness as a Cruise Tourism Destination. Unud's work book for the Nation's Children. Udayana University.

Suhanadji \& Waspodo, T.S. (2006). Modernization and Globalization: Development Studies in a Global Perspective. Yogyakarta: PT Insan Cendikia.

Sukarma, I. W. (2008). Pariwisata Bali Pascabom Kute. dalam Yudhis M. Burhanuddin, Bali yang Hilang: Pendatang, Islam dan Etnisitas di Bali. Yogjakarta: Kanisius.

Sukawati, T.A.A. (2004). Ubud Moves. Denpasar: CV. Bali Media Adhikarsa

Sumada, I.K. (2004). The existence of the Sadhaka in the Concept of Hinduism. Mataram: STAHN Gde Pudja Research Report.

Sunaryo. (2000). Social Research Methods, An Introduction. Malang: IKIP Malang.

Suyadnya, I.W. (2010). Reconsideration of Indonesian Tourism Travel: Poverty as an Oppositional Concept. Papers, National Seminar on Tourism and Poverty Alleviation, Ministry of Culture and Tourism of the Republic of Indonesia and Faculty of Tourism, Udayana University, Denpasar.

Tan, J. H. (2006). Religion and social preferences: An experimental study. Economics Letters, 90(1), 60-67. https://doi.org/10.1016/j.econlet.2005.07.006 
Tilaar, H. A. R. (2003). Kekuasaan dan pendidikan: Suatu tinjauan dari perspektif studi kultural. IndonesiaTera.

Triguna, I.B.G.Y. (2002). Social Change and Efforts to Preserve Balinese Culture: The Philosophy of Science Perspective, Masters Program in Religion and Culture, Universita Hindu Indonesia, Denpasar.

Wood, R. (2002). Carribean of the East? Global interconnections and the Southeast Asian cruise industry. Asian Journal of Social Science, 30(2), 420-440.

Wood, R. E. (2000). Caribbean cruise tourism: Globalization at sea. Annals of tourism research, 27(2), 345-370. https://doi.org/10.1016/S0160-7383(99)00073-0

Diana, I. N. ., Gelgel, . I. P. ., \& Dharmika, I. B. . (2020). Changes in work ethos of balinese who have worked on cruise ship and its implications for religious life and social culture. International Journal of Linguistics, Literature and Culture, 6(6), 36-47. https://doi.org/10.21744/ijllc.v6n6.1034 